\title{
Pelatihan Es Krim Sehat dan Bergizi Bagi Ibu-Ibu PKK untuk Meningkatkan Nilai Gizi Keluarga Serta Peluang Wirausaha Rumah Tangga di Kota Samarinda
}

\author{
I Wayan Sudarmayasa ${ }^{\mathrm{a}, 1,{ }^{*}, K}$ Krishna Anugrah ${ }^{\mathrm{b}, \mathrm{c}, 2}$, dan Kristian Triatmaja Raharja ${ }^{\mathrm{b}, 3}$ \\ ${ }^{a}$ Politeknik Negeri Samarinda, Kota Samarinda, 75132, Indonesia \\ ${ }^{b}$ Universitas Negeri Gorontalo, Kota Gorontalo, 96128, Indonesia \\ ${ }^{c}$ Politeknik NSC Surabaya, Kota Surabaya, 60271, Indonesia \\ ${ }^{1}$ darmapolnes@yahoo.com*; 2 qnaaa@gmail.com; ${ }^{3}$ kristiantraharja@gmail.com \\ * corresponding author
}

ARTICLE INFO (8 pt)

Article history:

Received

Revised

Accepted

\section{ABSTRACT}

The role of mothers today can no longer be ruled out for their role in domestic life. Mothers have been able to sustain family sustainability, especially in the economic field. Mothers can only wait at home and stand by and wait for their husbands, but they can play a greater role in supporting the economic needs of their families. But the question is whether mothers already have the skills to help support their family's economic needs? Based on this background, the authors conducted skills training for mothers, especially those who joined the PKK group by teaching ice cream making skills. In this article we will discuss the training that will be given starting with the basic introduction, equipment, processing, packaging process so that they can sell to get profits for them. The training that takes place in the Ketupat samarinda village across from this can later be expected by the mothers after the training will have the skills and can apply it at home so that it can help the family economy.

Keywords: Training, Skills, Ice Cream, Nutrition, Healthy Family.

Kata kunci: Pelatihan, Keterampilan, Es Krim, Gizi, Keluarga Sehat.

\section{ABSTRAK}

Peranan ibu-ibu pada masa sekarang ini tidak bisa lagi dikesampingkan peranannya di dalam kehidupan rumah tangga. Ibuibu sudah bisa menopang keberlanjutan keluarga khususnya dalam bidang ekonomi. Ibu-bu ukan hanya bisa menunggu dirumah dan berpangku tangan menunggu suami, namun sudah bisa berperan lebih lagi dalam menopang kebutuhan ekonomi keluarganya. Namun yang menjadi pertanyaan adalah apakah ibu-ibu sudah memiliki keterampilan untuk membantu menopang kebutuhan ekonomi keluarganya? Berdasarkan latar belakang inilah maka penulis melakukan pelatihan keterampilan bagi-ibu-ibu khususnya yang tergabung dalam kelompok PKK dengan mengajarkan keterampilan membuat es Krim. Dalam artikel ini nantinya akan dibahas tentang pelatihan yang akan diberikan mulai pengenalan dasar, peralatan, proses pengolahan,proses pengemasan hingga bisa menjual dengan mendapatkan keuntungan bagi mereka.Pelatihan yang mengambil tempat di kampung ketupat samarinda seberang ini nantinya bisa diharapkan para ibu-ibu setelah pelatihan akan memiliki keterampilan dan bisa memnerapkannya dirumah sehingga bisa membantu perekonomian keluarganya.

Copyright (C) 2019 Politeknik Negeri Samarinda. All rights reserved. 


\section{Pendahuluan}

Kota Samarinda memiliki sejuta potensi yang sangat mendukung akan perkembangan Kota di masa mendatang. Sebagai bagian dari wilayah yang akan dijadikan calon ibukota negara, Kota Samarinda memiliki sejumlah potensi wisata yang beranekaragam mulai dari wisata alam, wisata buatan, wisata budaya, maupun daya tarik wisata lain yang cukup menjanjikan. Kota Samarinda yang memiliki 10 kecamatan dan 59 kelurahan, memiliki penduduknya mencapai 766.015 jiwa dengan luas wilayah $783,00 \mathrm{~km}^{2}$ dan sebaran penduduk 978 jiwa $/ \mathrm{km}^{2}$, berdasarkan data tahun 2017.(Anon 2019a). Salah satu kecamatan yang ada di Kota Samarinda adalah Kecamatan Samarinda Seberang. Kecamatan Samarinda Seberang yang memiliki 6 (enam) Kelurahan yaitu kelurahan Baqa, Kelurahan Masjid, Kelurahan Sungai Keledang, Kelurahan Tenun, Kelurahan Gunung Panjang dan Kelurahan Mangkupalas (Anon 2019b).

Kawasan Samarinda Seberang merupakan kawasan yang berada di wilayah yang dibatasi oleh bentangan sungai mahakam dan berseberangan dengan kota Samarinda. Untuk masuk ke wilayah Samarinda Seberang bisa melewati jembatan Mahakam yang membentang di atas sungai Mahakam. Banyak potensi wisata yang ada di wilayah Samarinda Seberang, mulai wisata Sungai, Wisata susur sungai, Kampung Tenun, Kampung Ketupat,Masjid Tua hingga daya tarik wisata manik-manik.

Kampung Ketupat merupakan salah satu kampung yang berada di di kawasan dalam kelurahan Mesjid Kecamatan Samarinda Seberang . Kelurahan Masjid merupakan wilayah pemekaran kelurahan yang ada di wilayah Kecamatan Samarinda Seberang, dimana kelurahan baru di wilayah Samarinda Seberang ini memiliki potensi wisata dan bahkan sudah menjadi ikon serta kebanggaan dari Kota Samarinda, dan bahkan sudah dicanangkan sebagai salah satu destinasi kunjungan wisata nasional sebagai kampung perajin yang ramah lingkungan. Dari potensi yang dimiliki oleh wilayah kampung ini serta dukungan dan dorongan dari pemerintah Kota Samarinda menjadikan potensi ini sangat menjanjikan bagi masyarakat sekitar wilayah kelurahan masjid, baik dari potensi wisata yang menjanjikan, terpeliharanya warisan budaya nan luhung dari leluhur terdahulu, pemandangan yang sangat bagus baik dari tepi sungai ataupun pemandangan jembatan mahkota II. Kampung yang terdiri dari 21 RT dengan jumlah penduduk sebanyak 24.137 yang terdiri dari 12.368 orang laki-laki dan 11.769 wanita ini, penduduknya rata-rata bekerja sebagai pengrajin ketupat. (Rusmulyadi 2018).

Dengan potensi yang dimiliki oleh kampung ketupat, secara otomatis akan membuat wisatawan akan banyak mengunjingi daerah tersebut dengan berbagai latar belakang, golongan, profesi yang berbeda-beda karakternya. Untuk itulah perlu kiranya masyarakat bukan hanya sebagai penonton semata dengan kedatangan wisatawan kesana, namun ikut berperan walaupun sedikit tetapi bisa nantinya berperan aktif dalam kampung dalam mendukung kampung ketupat sebagai destinasi wisata. Ada berbagai hal positif yang bisa dilakukan oleh warga dalam mendukung keberadaan kampung ketupat ini sebagai destinasi antara lain aktif langsung sebagai pramuwisata, belajar sejarah akan kampung ketupat, serta berwirausaha makanan yang nantinya bisa dijual kepada wisatawan disekitar lokasi destinasi wisata.

Berdasarkan hal tersebut penulis memiliki ide untuk melakukan pelatihan makanan yang bisa dijual kepada wisatawan yang gampang dibuat, sehat bergizi, dan menjadi kesukaan semua kalangan. Dengan berbagai pertimbangan itulah akhirnya dipilih untuk melakukan pelatihan es krim. Es krim banyak manfaatnya bagi semua orang khususntya wisatawan baik suasana panas maupun kondisi yang tidak terlalu dingin. Ada beberapa manfaat es krim yaitu menurunkan berat badan, kesuburan, nutrisi, kekebalan, kesehatan seksual dan bangun mood ketika suasana tidak baik.(Salbiah and Virdhani 2019).

Dengan pelatihan es krim ini nantinya diharapkan terciptanya lapangan pekerjaan bagi masyarakat, khususnya para ibu-ibu sebagai salah satu Usaha Kecil Menengah (UKM) sehingga secara tidak langsung akan bisa meningkatkan pendapatan serta 
peningkatan taraf hidup bagi masyarakat setempat.Selain itu pula, bukan hanya untuk kebutuhan wisatawan, es krim hasil buatan sendiri ini nantinya bisa dikonsumsi dengan aman oleh keluarga mereka.

Di samping itu, pula potensi berjualan di area destinasi wisata yang sangat besar ini, nantinya pelatihan akan menggunakan berbagai perisa makanan dengan berbagai macam untuk membuat es krim.Dengan bekal pelatihan ini nantinya para pembeli tidak bosan tiap hari dan bisa berganti rasa yang ada dalam es krim tersebut. Maka dengan pertimbangan tersebut, penulis memilih es krim sebagai objek pelatihan dikarenakan menguntungankan berbagai pihak.(Silalahi and M.Trisno 2016).

Peserta pelatihan ini menyasar para ibuibu kelompok PKK yang memiliki waktu untuk melakukan pelatihan dan banyak memiliki waktu luang untuk mau bekerja nantinya dirumah dalam membantu perekonomian keluarga. Dengan pelatihan ini ibu-ibu akan diajarkan pengetahuan mulai awal yaitu pemahaman dan pengenalan alat, cara pengolahan, sampai mengemas es krim tersebut dalam tempat yang siap dijual.

\section{Review Tinjauan Pustaka (dicetak tebal, 11 font)}

Dalam penulisan ini ada beberapa acuan yang dijadikan tinjauan pustaka, antara lain :

\section{A. PELATIHAN}

Pelatihan didefinisikan bahwa Pelatihan adalah proses mengajarkan karyawan baru atau yang ada sekarang, keterampilan dasar yang mereka butuhkan untuk menjalankan pekerjaan mereka" (Dessler 2009). Sedangkan pada definisi lain, dijelaskan bahwa pelatihan merupakan suatu perbaikan kinerja dan meningkatkan motivasi kerja para karyawan yang dibebankan padanya, sehingga karyawan mengalami kemajuan dalam hal pengetahuan, keterampilan dan keahliannya sesuai dengan bidang pekerjaannya. Pelatihan juga sering dipasangkan dengan pendidikan.(Elfrianto 2017). Pelatihan secara tidak langsung juga akan mempunyai pengaruh yang signifikan terhadap disiplin bekerja karyawan/para peserta pelatihan (Elfrianto 2017) Pelatihan juga akan membutuhkan berbagai manfaat bagi semua yang terlibat di dalamnya. Dalam kegiatan pelatihan ini para peserta tentunya dibedakan dengan pelatihan yang dilakukan bagi karyawan atau bagi para siswa yang dari semua aspek memiliki kelebihan dan keutuhan akan performa mengikuti pelatihan. Ini dikarenakan pesertanya adalah para ibuibu kelompok PKK, maka pelatihan harus dilakukan dengan cara yang fleksibel menyesuaikan dengan waktu, kondisi di lapangan serta kebutuhan yang diperlukan biar bisa paham dan mengerti dengan baik.

\section{B. UKM}

Usaha Kecil Menengah atau sering disingkat UKM adalah eputusan Presiden RI no. 99 tahun 1998 pengertian Usaha Kecil adalah: "Kegiatan ekonomi rakyat yang berskala kecil dengan bidang usaha yang secara mayoritas merupakan kegiatan usaha kecil dan perlu dilindungi untuk mencegah dari persaingan usaha yang tidak sehat."(Presiden 1998) Dalam keputusan presiden tersebut juga disebutkan ada beberapa komponen kriteria dari usaha kecil yaitu:

a. Memiliki kekayaan bersih paling banyak Rp. 200.000.000,- (Dua Ratus Juta Rupiah) tidak termasuk tanah dan bangunan tempat usaha

b. Memiliki hasil penjualan tahunan paling banyak Rp. 1.000.000.000,- (Satu Miliar Rupiah)

c. Milik Warga Negara Indonesia

d. Berdiri sendiri, bukan merupakan anak perusahaan atau cabang perusahaan yang tidak dimiliki, dikuasai, atau berafiliasi baik langsung maupun tidak langsung dengan Usaha Menengah atau Usaha Besar

e. Berbentuk usaha orang perorangan, badan usaha yang tidak berbadan hukum, atau badan usaha yang berbadan hukum, termasuk koperasi.

Sedangkan ada perbedaan antara UKM dan UMKM, yang mana merujuk pada undang-undang Nomor 20 Tahun 2008 tentang usaha mikro, Kecil Dan Menengah, disebutkan Bahwa usaha produktih milik perorangan dan atau milik badan perseorangan yang memenuhi kriteria usaha mikro yang asetnya maksimal Rp. 
$50.000,000,00$ dan maksimal omsetnya Rp. 300.000.000,00 (Aryadji 2019).

\section{GIZI}

Gizi atau Nutrisi merupakan zat yang terdapat pada makanan yang dibutuhkan oleh organisme untuk pertumbuhan serta perkembangan yang dimanfaatkan langsung oleh tubuh yang meliputi vitamin, mineral, protein, lemak maupun air. Adapun zat gizi didapat dari makanan yang diperoleh dalam bentuk sari makanan dari hasil proses pemecahan pada saat dalam sistem pencernaan.Selain itu, Zat gizi terbagi menjadi 2 yakni zat gizi organik \& zat anorganik. Adapun zat gizi organik ini yakni seperti lemak, karbohidrat, protein, dan vitamin. Sementara zat gizi anorganik yakni terdiri dari air dan mineral (Mughnifar Ilham 2019).

\section{WIRAUSAHA}

Wirausaha diartikan adalah seseorang yang terbilang pandai atau memiliki bakat dalam mengenali produk baru, pandai dalam menentukan cara produksi yang baru, pandai dalam menyusun operasi dalam pengadaan produk baru, pandai dalam memasarkan produk serta pandai pula dalam mengatur perputaran modal operasi usahanya. Dalam KBBI kata wirausaha ini sepadan dengan wiraswasta. Adapun pengertian wirausaha secara umum yakni seseorang yang memiliki keberanian mengelola usaha secara mandiri menggunakan segala sumber daya yang ia miliki. Dengan demikian, bisa pula disebutkan bahwa wirausaha ini adalah orang-orang yang berani dalam menghadapi segala resiko dalam usahanya.Seorang wirausaha memiliki ciri-ciri atau karakteristik tersendiri, yakni:Mempunyai keberanian serta daya kreasi dan inovasi yang baik Sanggup dan berani berhadapan dengan resiko,Mempunyai daya analisa yang baik dan tepat, tidak konsumtif, Memiliki tekad juga kemauan yang keras, Jiwanya adalah jiwa seorang pemimpin yang senantiasa berorientasi ke masa depan (KBBIdaring 2019).

\section{Metodologi Penelitian}

Metode kegiatan dalam pengabdian pada masyarakat ini adalah menggunakan metode deskriftif kualitatif yang mana data Pelatihan membuat es krim mulai dari pemilihan bahan hingga penghitungan bahan yang dilakukan nantinya akan dijelaskan dan dipaparkan secara terinci sesuai dengan kegiatan itu dilakukan. Data komponenkomponen yang didapat dari pelatihan itu tersebut nantinya akan dipaparkan sesuai pelatihan yang didapatkan. Pada metode pelatihan ini akan dititikberatkan pada keterlibatan masyarakat dalam menumbuhkan jiwa wirausaha bagi pemilik wilayah pariwisata agar bisa berkembang dan mengikuti arus perubahan zaman dengan membekali dirinya keterampilan usaha khususnya es krim.Data yang didapat nantinya adalah yang pertama adalah sasaran primer dari kegiatan program pelatihan ini seperti potensi, serta ibu-ibu yang potensial dan tidak memiliki kegiatan atau aktivitas tetap.dan yang kedua adalah sasaran sekunder dalam kegiatan pengabdian masyarakat ini adalah kelompok ibu-ibu dan masyarakat mendapatkan pengetahuan dan keterampilan serupa dalam rangka kaderisasi sebagai pengelola kegiatan wisata serta menjadi pelaku langsung wisata bagi anggota masyarakat atau pemuda potensial dan dapat memberikan pelatihan dan kontribusi yang baik bagi pelaku kuliner lokal.

\section{Hasil dan Diskusi}

Pelatihan pembuatan Es Krim ini dilaksanakan selama 2 hari Adapun kegiatan ini dikuti oleh kurang lebih 25 orang peserta yang diajarkan oleh instruktur yang berpengalaman di bidangnya, khususnya es krim. Metode yang digunakan adalah penyuluhan dan demonstrasi agar lebih mengenal dengan cepat (Miksusanti, fatma, suheryanto, budi untari n.d.) Kegiatan ini dilakukan selama 2 hari ini memiliki rincian sebagai berikut yaitu: hari pertama para peserta mengikuti pelatihan materi pembuatan es krim secara teori antara lain:

a. Cara memilih dan mencari bahan yang cocok untuk es krim.kegiatan ini. Dalam kegiatan yang dilakukan adalah memilih bahan yang cocok baik dari harga, merek, kandungan serta bahan yang cocok untuk es krim sangatlah berbeda dengan bahan membuat adonan lain. Ini dikarenakan semua bahan tidak selalu cocok ketika 
membuat es krim seperti halnya dalam pemilihan susu.

b. Takaran komposisi yang tepat, Takaran komposisi dalam membuat es krim haruslah memakai bahan yang tepat. Takaran ini akan sangat mempengaruhi rasa serta kualitas produk yang dihasilkan.apabila salah dan jumlah takaran yang tidak seimbang maka akan mempengaruhi akan produk yang dihasilkan nantinya.

c. Penggunaan Alat, Dalam menggunakan alat para peserta juga diberikan teori atau cara menggunakan peralatan mulai dari menghidupkan, memakai peralatan sampai mematikan hingga mengembaikan ke tempat semula. Karena kalau hal ini tidak dilakukan, maka bisa akan merusak peralatan yang dikarenakan oleh ketidaktahuan peserta mengoperasikan alat yang dipakai.

d. Cara mengukur takaran yang pas.dalam membuat es krim para peserta latihan cara mengukur takaran yang pas agar tidak ada perbedaan rasa antara satu peserta dengan yang lainnya. Jadinya nantinya siapapun yang membuat kualitas rasa dan kualitasnya tidak akan berubah.

e. Kemudian yang terakhir adalah mengajarkan para peserta cara menghitung Cost. Hal ini dilakukan agar Peserta pelatihan ketika akan menjual produknya sangat perlu mengetahui menghitung kalkulasi pengeluaran bahan yang dikeluarkan, harga penjualan per kemasan dengan banyaknya bahan yang dibeli sehingga para peserta yang nantinya mau berwirausaha tidak akan mengalami kerugian.

Table 1. Rincian asumsi biaya pembuatan es krim

\begin{tabular}{|c|c|c|c|c|}
\hline No & $\begin{array}{l}\text { Nama Bahan } \\
\text { \& Alat }\end{array}$ & $\begin{array}{l}\text { Ukuran } \\
\text { Bahan }\end{array}$ & $\begin{array}{l}\text { Harga } \\
\text { Satuan }\end{array}$ & Biaya \\
\hline 1 & $\begin{array}{l}\text { Susu ice full } \\
\text { cream }\end{array}$ & $400 \mathrm{gr}$ & $55.000 / \mathrm{gr}$ & 55.000 \\
\hline 2 & Gula pasir & $800 \mathrm{gr}$ & $\begin{array}{l}16.000 / 1.000 \\
\text { gr }\end{array}$ & 12.000 \\
\hline 3 & Agar-agar & 1 bungkus & $3.500 / \mathrm{bks}$ & 3.500 \\
\hline 4 & Quick & $100 \mathrm{gr}$ & $6.500 / 100 \mathrm{gr}$ & 6.500 \\
\hline 5 & Air Mineral & 4 liter & $1.000 /$ liter & 1.000 \\
\hline 6 & 3 Perisa & $100 \mathrm{ml}$ & $\begin{array}{l}20.000 / 100 \\
\mathrm{ml}\end{array}$ & 60.000 \\
\hline 7 & Cup 1 Liter & 1 resep & $20.000 /$ resep & $\begin{array}{l}20.000 \\
153.000\end{array}$ \\
\hline
\end{tabular}

Sources: resep pribadi

Kemudian di hari kedua para peserta diajarkan melakukan pelatihan atau praktikum secara langsung cara membuat es krim. Dalam pelatihan ini peserta di bagi menjadi 2 kelompok yaitu shift pagi dan shift siang yang terbagi menjadi masing-masing berjumlah 12 dan 13 Orang. Ini dilakukan untuk mengefektifkan kegiatan pelatihan. Para peserta mendapatkan pelatihan mulai dari cara menakar masing-masing bahan yang yang dipakai yaitu air matang, agaragar yang bening, quick (emulsifier) yaitu pengemulsi khusus pada segala macam adonan (Wijayanti 2018), gula pasir, susu full creamyang mengandung lemak 3,25\% (Miksusanti, fatma, suheryanto, budi untari n.d.) dan perisa makanan asli untuk menjaga kualitas ice cream dan keamanan konsumen. Dalam prosesnya pembuatan es krim diawali dengan menyiapkan bahan dan alat, sambil memanaskan air. Proses selanjutnya adalah memasukan agar-agar sesuai tahapan dan dilakukan dengan diaduk secara bertahap. Proses selanjutnya adalah memnaskan adonan kembali , memasukan susu full cream dan diaduk selama kurang lebih 15 menit dan kemudian membekukan adonan sesuai kebutuhan waktu yang dibutuhkan kurang lebih 6 jam. Setelah adonan beku, kemudian dipotong dan diaduk sampai mengembang sambil kemudian mencampur bahan perisa ke dalam es krim selama kurang lebih 20 menit. Setelah semuanya rata, es krim kemudian ditempatkan pada tempat yang diinginkan sesuai kebutuhan yang diperlukan dan dibekukan selama kurang lebih 6 jam sebelum es krim siap dikonsumsi.

\section{Kesimpulan}

Dari hasil kegiatan pelatihan es krim ini para peserta kegiatan sangat antusias akan kegiatan pelatihan yang dilakukan dan mengharapkan dilaksanakan setiap tahunnya dengan tema yangberbeda-beda.para peserta setelah mengikuti kegiatan ini akhirnya mengerti akan cara membuat es krim dan ternyata sangat mudah untuk dilakukannya sehingga para peserta ingin melaksanakan hasil pembuatan es krim ini di waktu yang akan datang di rumah baik untuk keluarga maupun membuka usaha kalau ada modal usaha. Dengan pelatihan ini nantinya akan bisa dilanjutkan untuk program lain dimasa mendatang kepada segala lapisan masyarakat bawah khususnya ibu rumah tangga yang memiliki waktu dan mau berkreatifitas. Selain itu pula perlu dilakukan 
pendampingan keterampilan ini agar bisa diteruskan di masa mendatang dengan kelompok masyarakat luas dari satu daerah ke daerah lainnya.

\section{References}

[1] Anon. 2019. "Kecamatan Di Kota Samarinda."

Https://samarindakota.bps.go.id/. Retrieved (https://samarindakota.bps.go.id/).

[2] Anon. 2019b. "Kecamatan Samarinda Seberang Dalam Angka 2019.” BPS Kota Samarinda. Retrieved December 18, 2019 (https://samarindakota.bps.go.id/publication/ 2019/09/26/268228c41d544e3bf3d805e3/ke camatan-samarinda-seberang-dalam-angka2019).

[3] Aryadji. 2019. "Apa Beda UKM Dengan UMKM, Ini Penjelasannya." Http://www.berdesa.com. Retrieved (http://www.berdesa.com/apa-beda-ukmdengan-umkm-ini-penjelasannya/).

[4] Dessler, Gary. 2009. Manajemen Sumber Daya Manusia. 1st ed. Jakarta: indeks.

[5] Elfrianto. 2017. "Pengaruh Pelatihan Dan Pengembangan Terhadap Disiplin Kerja Dan Kinerja Karyawan.” Jurnal Manajemen Dan Kewirausahaan 5:8-21.

[6] KBBIdaring. 2019. "Pengertian Wirausaha." KBBI. Retrieved (https://kbbi.kemdikbud.go.id/).

[7] Miksusanti, fatma, suheryanto, budi untari, yulinar adnan. n.d. "Training Pembuatan Selai Dan Es Krim Labu Kuning Sebagai Makanan Untuk Kesehatan.” Jurnal Pengabdian Sriwijaya 57-62. Retrieved (https://www.kompasiana.com/leoric/5c19ed 3e43322f59a157c414/perbedaan-susu-skim- dengan-susu-full-cream-manakah-yangcocok-untuk-diet).

[8] Mughnifar ilham. 2019. "Pengertian Gizi Menurut Para Ahli, Macam-Macam Dan Fungsi Gizi.” Materibelajar.go.id. Retrieved December $\quad 19, \quad 2019$ (https://materibelajar.co.id/pengertian-gizimenurut-para-ahli-macam-macam-danfungsi-gizi/).

[9] Presiden, Keputusan. 1998. Keputusan Presiden (KEPPRES) Tentang Bidang/Jenis Usaha Yang Dicadangkan Untuk Usaha Kecil Dan Bidang/Jenis Usaha Yang Terbuka Untuk Usaha Menengah Atau Usaha Besar Dengan Syarat Kemitraan. Indonesia.

[10] Rusmulyadi, S.So. 2018. "Pemuda Kampung Ketupat Didorong Berwirausaha." Disporakaltim

[11] Salbiah, Nurul Adriyana and Marieska Harya Virdhani. 2019. "Takut-GemukTernyata-Ini-8-Manfaat-Makan-Es-Krim/." Jawapos.com. Retrieved December 17, 2019 (https://www.jawapos.com/kesehatan/health -issues/10/04/2019/takut-gemuk-ternyataini-8-manfaat-makan-es-krim/).

[12] Silalahi, Perwira and M.Trisno. 2016. "Pelatihan Pembuatan Es Krim Untuk Peningkatan Kualitas Dan Produksi UKM Kelurahan Ciptomulya Kecamatan Sukun Kota Malang." Seminar Nasional Inovasi Dan Aplikasi Teknologi Industri SENIATI) A177-79.

[13] Wijayanti, Endah. 2018. "Mengenal Cake Emulsifier (Ovalet, TBM, Dan SP)." FIMELA. Retrieved December 19, 2019 (https://www.fimela.com/lifestylerelationship/read/3857577/mengenal-cakeemulsifier-ovalet-tbm-dan-sp). 